\title{
Why do medical students learn about primary care?
}

\section{Dr Anne Stephenson}

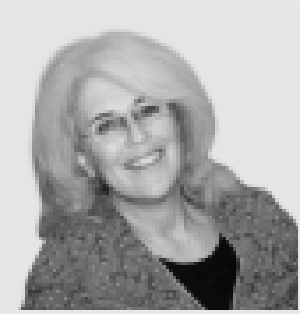

Dr. Anne Stephenson は, 1977 年に ニュージーランドの Otago Medical School を卒業後, 1990 年には英国キン グス大学にて医学教育を担当され，1994 年から Deparment of General Practice and Primary Care の卒前教育の責任者 となられています。（キングス大学では 最終学年にプライマリ・ケア現場で 8 週 間の臨床実習が行われています.)

医学教育に関する論文だけでなく教科 書なども執筆されご活躍中ですが, GP として地域のオフィスで診療もされてい ます．お裹さんともども日本の文化にと ても関心がある親日家でもいらっしゃい ます.（東京慈恵会医科大学 臨床疫学 研究室 松島雅人)
There is overwhelming evidence that a strong primary health care service produces "better health outcomes at lower cost ${ }^{\prime}{ }^{1,2)}$ and in many countries, including the United Kingdom, primary care is the foundation of the healthcare system. In the UK $90 \%$ of NHS contacts take place in general practice where about one million consultations take place each $\mathrm{day}^{33}$. At present one third of the 160,000 doctors in the UK are general practitioners $^{4)}$ and, with the increasing demand for primary care, government plans are to increase that number to at least half of all graduates ${ }^{5)}$.

The latest UK General Medical Council directive for medical schools, 'Tomorrow's Doctors 2009' ${ }^{6}$ ), states that 'placements should reflect the changing patterns of healthcare and must provide experience in a variety of environments including hospitals, general practices and community medical services'. Over the past 15 years the teaching of primary care in UK medical schools has grown to reflect this reality and has now reached an average of $13 \%$ of the teaching in medical curricula ${ }^{7)}$.

So why is learning about primary care so important for medical students? A recent paper by Pearson and McKinley ${ }^{8)}$ suggests that it trains doctors 'where people live, work, stay healthy and become unwell', teaches doctors about 'the conditions most patients suffer', and provides an understanding of 'the demands of the changing face of primary care'. This is important for all doctors, whether or not they will become general practitioners. Where primary care is strong there is an added imperative to educate doctors about the 'management most patients experience' and 'train doctors where most doctors will practise' .

The general practitioner, as generalist, is well placed to teach core knowledge, skills and behaviours to all doctors in training as well as the specific demands and realities of primary care. Primary care, where it is practiced best, is where patients have first contact access within the health system ; provides long term person-focused care with orientation toward the family and community, comprehensive care for most health needs, and coordinated care when it must be sought elsewhere ;

Dr Anne Stephenson MBChB, MRCGP, Dip. Obst., PhD (Medicine), FHEA

Director of Community Education

King's College London

Department of Primary Care and Public Health Sciences 
and has a specific responsibility for the health of the community ${ }^{9)}$.

Medical students placed in primary care learn about specific decision making processes determined by the prevalence and incidence of illness in the community. They experience a unique consultation process where effective communication means that a relationship with the patient is established over time. They can begin to manage illness that presents in an undifferentiated way, manage in the same patient both acute and chronic health problems, deal with uncertainty, and understand all this in its physical, psychological, social, cultural and transpersonal dimensions. Team care, so important in primary care, helps the students be aware of and work with other practitioners. The students' largely disease-oriented medical training can be balanced in primary care with an emphasis on health as well as illness with preventative care and health promotion becoming an increasingly important responsibility of primary care practitioners. Finally, in the context of available resources, a focus on balancing the needs of individual patients with those of the whole community provides a realistic view of a country's healthcare system.

The development of primary care teaching in medical schools is faced by challenges of capacity, political will, and change in the way primary care services are delivered ${ }^{8}$. However in a world where primary care is the key to an equitable and effective health system, medical students must gain an understanding of the importance of treating all patients in the context of patients' lives, families and communities.

\section{References}

1) Starfield, B. ; Shi, L, ; Macinko, J. Contribution of primary care to health systems and health. Milbank Q. 2005, vol. 83, p. 457-502

2) Rawaf, S. ; De Maeseneer ; Starfield, B. From Alma-Ata to Almaty : a new start for primary health care. The Lancet. 2008, vol. 372, no. 9647, p. 13651367.

3) Gregory, S. General practice in England : An overview. London : The King's Fund, 2009

4) NHS Choices Homepage-Your Health, Your Choices. http://www.nhs.uk/ NHSEngland/thenhs/about/Pages/overview. aspx (last checked 06 March 2010)

5) Department of Health. A High Quality Workforce : NHS Next Stage Review. London : Department of Health, 2008

6) General Medical Council. Tomorrow's Doctors. London : GMC, 2009

7) Jones, R. ; Stephenson, A. Quality assurance of community-based undergraduate medical curricula by academic departments : Cross sectional survey. Education for Primary Care. 2008, vol. 19, p. 135-142.

8) Pearson, D. J. ; McKinley, R. K. Why tomorrow's doctors need primary care today. J R Soc Med. 2010, vol. 103, p. 9-13

9) European Academy of Teachers in General Practice. The European Definition of General Practice/Family Medicine. Short Version EURACT, 2005. http://www.euract.org/index.php?folder_id = 25 (last accessed 06 March 2010) 